\title{
Application of Blasting Compacting Method for Filling Stone in Foundation Construction of Revetment \\ BaoChu Yu ${ }^{1, a}$, JiaSong Wang ${ }^{1, b}$,RongYang Sun ${ }^{2, c}$ \\ ${ }^{1}$ Dalian Ocean University,Dalian,Liaoning province,China \\ ${ }^{2}$ No.3 Engineering Company Ltd.Of CCCC First Harbor Engineering Company Ltd.,China

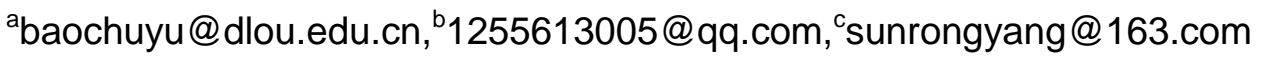

Keywords: blasting compacting method for filling stone; silt; soft foundation treatment; revetment

Abstract. Blasting compacting method for filling stone in dealing with deep silt and soft foundation, has prominent features of quick construction, low cost and excellent effect, etc.. This paper, focuses on paddy rice transfer program in China Grains \& Logistics Group North Grain Co. Limited and takes hydraulic engineering of scattered rice transit facility as an example, by introducing the practical application of method of blasting compacting method for filling stone in construction of revetment, aims to provide a reference for other similar projects.

\section{Introduction}

With the continuous development of coastal engineering,foundational execution conditions become more complicated and difficult.As an effective treatment method of soft foundation-blasting compacting method for filling stone, get more and more extensive application. In this artic ,revetment project has length of $1.4 \mathrm{KM}$, mainly in the form of a ramp-type structure. It uses $5300 \mathrm{KG}$ rubbles from the mountains for blasting compacting and filling stone and adopts segmented explosion with short time-separation interval to reduce the impact of blasting on surrounding buildings and waterways.

\section{Project profile}

Geographical location.Paddy rice transfer hydraulic engineering of China Grains \& Logistics Group North Grain Co. Limited is located in the east coast of Dalian Bay of Liaodong Peninsula, the west point of Dagushan Peninsula and the south sea area of existing breakwater in North Grain port.

Geological conditions.According to geological survey report, the strata in the exploration area are mainly Quaternary marine sediments and Sinian substrata. Marine strata primarily consist of silt and mucky silty clay; continental strata are mainly silty clay; and the lithology of Sinian Changling Group is mainly slate. Rock and soil layers in the part of revetment from top to bottom are:

1) silt: ash black dark gray, saturation, flow plastic soft plastic, uniform texture; allowable bearing $\mathrm{f}=30 \mathrm{KPa}$; thickness of $4.30 \sim 9.50 \mathrm{~m}$, average of $6.65 \mathrm{~m}$; layer bottom elevation of $-17.6 \sim$ $-22.8 \mathrm{~m}$.

2) mucky silty clay: dark gray, saturated very wet, soft plastic state, uniform texture; allowable bearing $\mathrm{f}=70 \mathrm{Kpa}$; thickness of $3.60 \sim 7.90 \mathrm{~m}$, average of $6.03 \mathrm{~m}$; layer bottom elevation of $-21.20 \sim$ $-29.40 \mathrm{~m}$, layer bottom depth of $10.40 \sim 16.60 \mathrm{~m}$; average of standard penetration test blow count $\mathrm{N}$ $=3.29(2 \sim 4)$, the exploration area are distributed.

3)clay: tawny $\sim$ taupe, wet, soft plastic $\sim$ plastic state, smooth knife surface, no shaking reaction, 
moderate toughness, moderate dry strength; allowable bearing $\mathrm{f}=130 \mathrm{Kpa}$; thickness of $0.80 \sim$ $6.60 \mathrm{~m}$, average of $3.45 \mathrm{~m}$; layer bottom elevation of $-26.2 \sim-32.50 \mathrm{~m}$, average of $-25.68 \mathrm{~m}$; layer bottom depth of $13.40 \sim 19.40 \mathrm{~m}$; average of standard penetration test blow count $\mathrm{N}=4.83(3 \sim 6)$; field area are distributed.

Surroundings. The nearest distance from blasting area, to the northwest of North Grain's existing breakwater is $80 \mathrm{~m}$; to the west side of North Grain channel is $181 \mathrm{~m}$; to the southeast of Omishima waterway is $681 \mathrm{~m}$; to the east side of ocean merchant ship terminal is $1396 \mathrm{~m}$; to the north side of North Grain $4^{\text {th }}$ light steel warehouse is $848 \mathrm{~m}$.

Design water level. According to the theoretic lowest tide level of Dalian, design water level is $3.51 \mathrm{~m}$; design of low water level is $0.03 \mathrm{~m}$; extreme high water level is $4.61 \mathrm{~m}$; extreme low water level is $-1.57 \mathrm{~m}$.

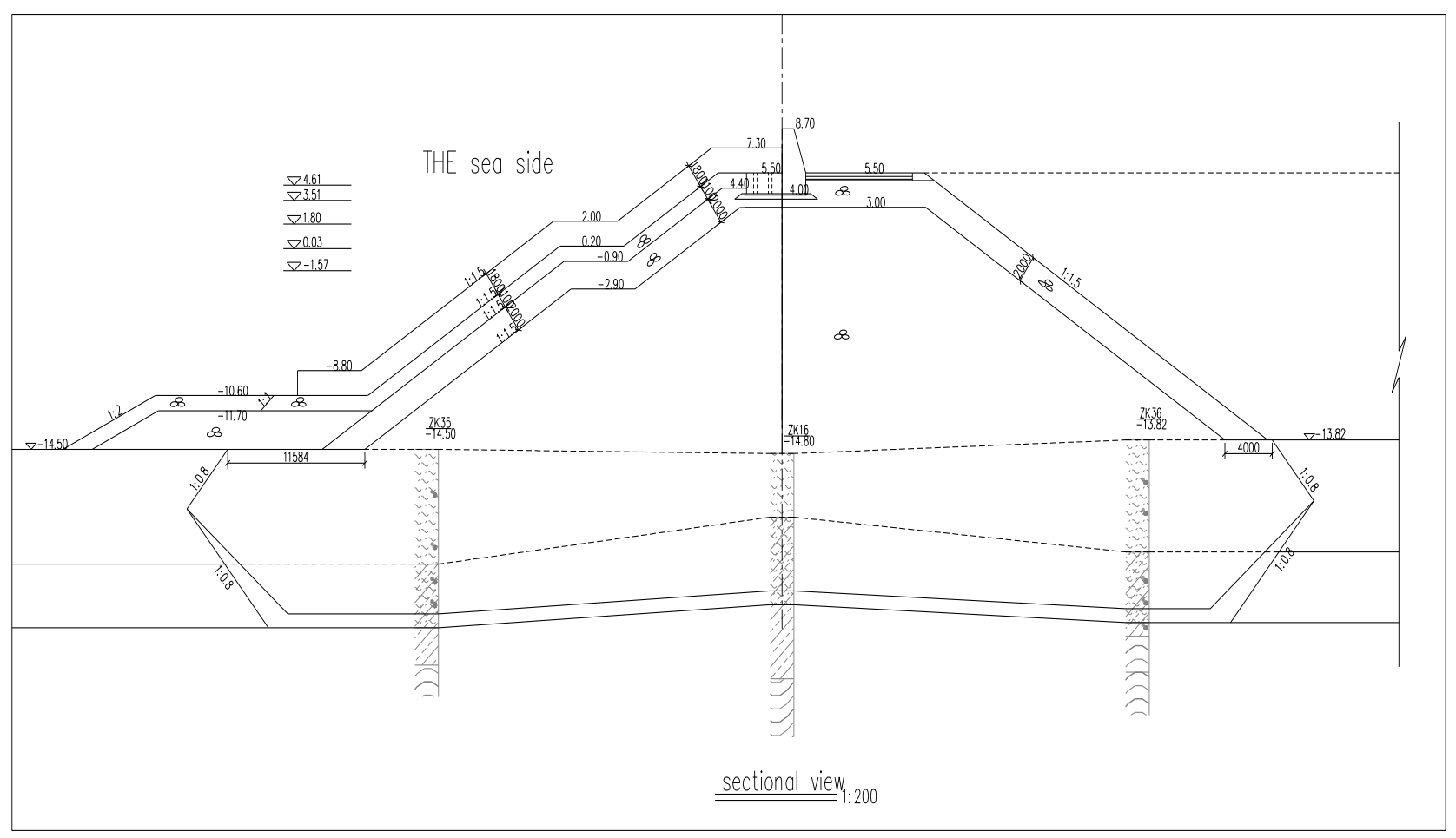

Fig.1:The sectional view of bank protection

\section{The theory of blasting compacting method for filling stone and its construction points}

The theory of blasting compacting method for filling stone.Multi charges are buried in the silt with proper distance from riprap mound on the end of breakwater. The powers generated by firing charges make the silt roll to the surroundings and form a blasting pit. With the joint action of vibratory force and gravity, the rock mound slip into the blasting pit and stop at the edge of excursive silt. Due to the vibratory effect, prisms at the ends fill in the pit room. After the above process, riprap mound and silt finish the replacement.

Construction points. In order to complete it better, we need to operate according to the following eight points.

1) Construction preparation: organize personnel and mechanical equipment and arrange well technique and secure exchange. 
2) Surveying: measuring personnel do the paying off based on design drawings and clearly identify the position to guide the backfilling work. Complete lofting at hanging flat station sites based on blasting scheme and place clearly mark to guide the arrangement of explosive.

3) Throwing fill breakwater core: backfill in strict accordance with the pay-off mark. Shall not exceed the fill and need to complement timely when lacking the stones. The quality of stones must be supervised and controlled. Among them, the mass of the most external stone should be larger to increase the blast effect. ${ }^{[1]}$

4) Before blasting, plug detection measurement: identify the scales on the blanking pipe, and have plug detection for once every $2 \mathrm{~m}$ and record the depth data. Measure before blasting is to test if the position of stone tongues change after the last blasting silt backfill; measure after blasting is to checkout whether the effect of blasting silt reach the planned footage.

5) Arrangement of explosive: according to blasting design, based on parallel line property theorem on one side of a triangle and Pythagorean theorem, transform the point location of cartridge bag into a series of points in coordinate which take the crane center as original point, transversal crossing the crane center as $\mathrm{X}$-axis and revetment positioning axes as Y-axis. In this way, crane stop only once, then complete the positioning by rotating the boom, which can not only improve the accuracy of location of explosive, but also save time and costs.

6) Connecting to the network, warning, detonating and releasing alert: this project adopt sectional time-lapse nonel detonator to detonate explosive. The energy of explosive spread very rapidly in the water, therefore, alert on water is very important, especially diving operations. Even though diving operations are in the safe area, they cannot be ignored. ${ }^{[2]}$

7) Seaside silt blasting on breakwater body: after finishing 100m's silt blasting on breakwater end, silt blasting on breakwater body can be operated and broadened within the range of $50 \sim 60 \mathrm{~m}$ each time. Its method is same as silt blasting on breakwater end.

8) Acceptance checks: in the process of construction, acceptance checks on the effect of silt blasting should be strengthened. In addition to plug detection and sounding survey, diving to explore the situation of back silting is necessary. And according to the thickness of silt, changes of soil and other situations, adjust the dose of explosive, space and silt blasting footage, etc.. ${ }^{[1]}$

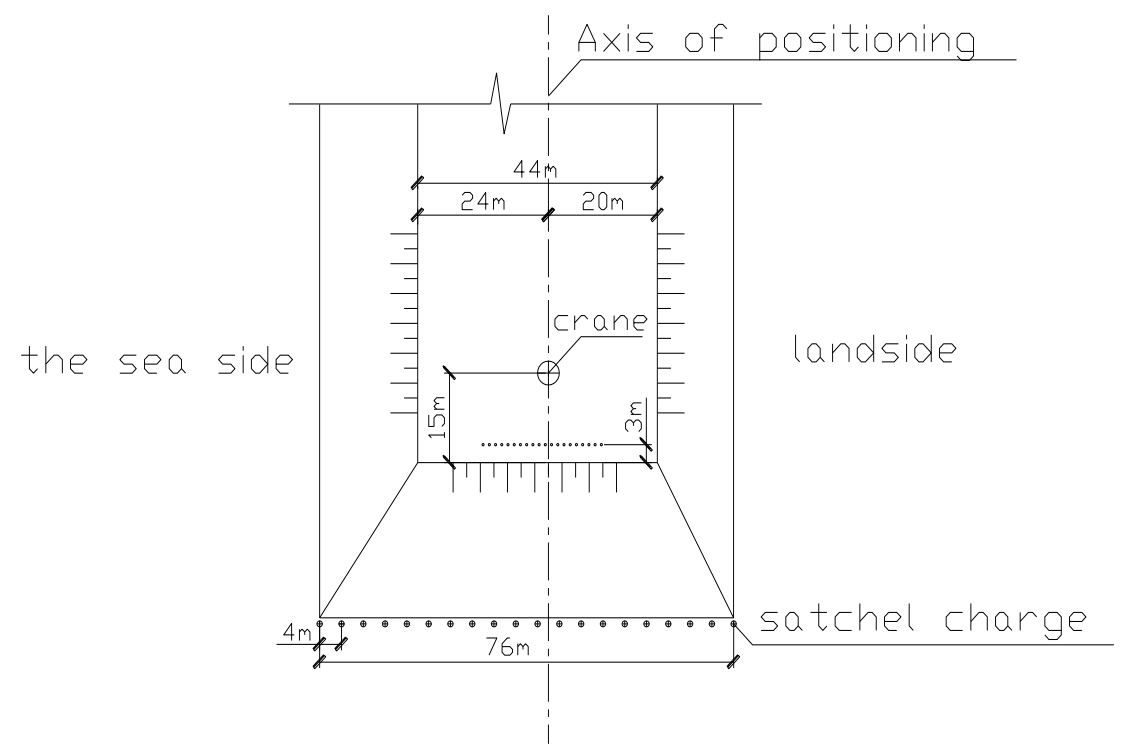

Fig.2 Diagram of blasting 


\section{Blasting parameter and explosive dose}

\section{Calculation of explosive dose for silt blasting.}

$$
\mathrm{Q}=q_{0} L_{H} H_{m w} L_{L}
$$

Where: Q-once blasting total dose; $q_{0}$-explosives unit consumption $(\mathrm{kg} / \mathrm{m} 3) ; L_{H}$-propulsive horizontal distance for once; $H_{m w}$-corrected silt thickness included covering water depth (m);

$$
H_{m w}=H_{m}+\left(\rho_{w} / \rho_{m}\right) H_{w}
$$

Where: $H_{m}$-the thickness of silt needs to replace, containing uplifting silt pack thickness; $p_{w}$-water density $(\mathrm{t} / \mathrm{m} 3) ; H_{w}$-covering water depth above the silt surface; $L_{L}$-the line length for once arranging explosive (m).

$$
H_{B}=(0.45 \sim 0.55) H_{m}
$$

Where: $H_{B}$-depth of the charge;

Parameter determination.According to Water Transport Engineering Blasting Technical Specifications JTS / 204-2008, combining with the actual construction experience, the parameters are determined as follows:

The average thickness of silt Hn-12.2m; depth of the charge H-7.3m; line-charge quantity $\mathrm{q}-21.35 \mathrm{~kg} / \mathrm{m}$; charge spacing a-4m; charge in per hole quantity $\mathrm{q}_{1}-80 \mathrm{~kg}$; the line length for arranging explosive $\mathrm{L}_{\mathrm{L}}-76 \mathrm{~m}$; the number of blasting cartridge-20; once blasting dose Q-1600kg. ${ }^{1]}$

\section{Quality standards and assurance measures}

Quality standards.Breakwater core rocks should fall on bearing stratum (the mixing layer of breakwater core rocks and bearing stratum should not be more than $1.0 \mathrm{~m}$ );Allowable deviation of cartridge production and arrangement: allowable deviation single charge dose should not be more than 5\%; deviation of charges' planimetric position should not be more than $10 \%$ of space between explosive charges;Probability of explosion for each time should not be less than $90 \%$. If less than $60 \%$, it should be added blasting once or partial blasted between $60 \%$ and $90 \%$. $^{[1]}$

Quality assurance measures. Organizers should tell all things about technique and safety to constructers;According to the effect of blasting compaction in test section, conclude experience to 
optimize parameters; Choose quality backfill materials and begin the construction of backfill from middle to two flanks; In the process of propulsive blasting on breakwater end and side blasting, the silt of two meters higher than soil surface which is squeezed out in the scope of breakwater body, apron stone and bottom protection stone can be eliminated by high-front shovel or by the method of cartridge bare blasting; After each blasting, examine the effect of blasting compaction. If the quality meets the requirement, construction can be getting into next step; if not, the parameters should be adjusted and blasting again until meeting the requirements.; Detect the effect of blasting compaction by the method of exploring fracture surface with explored stick or instrument for arranging explosive. Based on the progress of project, each completing the work of $200 \sim 300 \mathrm{~m}$, the third party entrusted by owners can detect the work by drilling to ensure blasting compaction can meet the design requirements.

Safety assurance measures. Safety management is an important step in project construction, only its security can be perfectly ensured, the progress of the project will be normal.

1) To establish the command institution for blasting operation and organizing institution of blasting personnel and formulate the system of personal responsibility.

2) To apply to the public security department and transact the blasting licence.

3) Strict adherence to Chinese Blasting Safety Rules to conduct construction.

4) To notify the first party, supervision and nearby units to avoid before blasting.

5) To cordon off the precautionary area before blasting, follow the principle of "three signals", make all constructers and nearby residents know the significance of alert, warning mark and acoustical signals and the methods and time of giving signals.

6) Do not carry out blasting at night or in heavy fog. Stop blasting in thunderstorms.

7) Blasting operation on water is not allowed when the wind force exceed sic grades.

8) Do not wear chemical fiber garment, shoes with nails to work on blasting operation and get into explosive storerooms, processing rooms, storage yard and other blasting sites.

9) Detonating cord, explosive and blasting cap must be transported and stored separately.

10) Cartridge bags and blasting network have been placed in underwater cannot be hauled. Explosive can be detonated after eliminating the abnormal phenomena like floating cartridge, damaged network route and so on.

11) Strengthen the precaution of typhoon, cold wave, heavy wind, rainstorm, hail and other severe weather. Take effective measure to protect the safety of personnel, equipment and revetment.

12) In strict accordance with the requirement of maximum explosive charge demand, to adopt sectional blasting, minimize the harm the noise, seismic wave and shock wave generated by blast to surrounding buildings (breakwater, No.4 lightweight steel storeroom, etc. ), ships and personnel. ${ }^{[2]}$

\section{Conclusion}

Blasting compacting method for filling stone observably improve treatment effect on deep soft foundation and greatly improve the stability of foundation beds. In the process of construction, silt-blasting effect can also be improved if taking full advantage of tidal action. After over one year of observing and analyzing on settlement, taking revetment foundation of blasting compaction, the average settlement is about $1 \mathrm{~cm}$ with the maximum $1.3 \mathrm{~cm}$ and the minimum $0.6 \mathrm{~cm}$ and settlement uniform without the phenomenon of ups and downs. Therefore, blasting compacting method for 
filling stone have obvious advantages in efficiency, cost, quality, operability and other aspects.

\section{References}

[1] Water Transport Engineering Blasting Technical Specifications , JTS 204-2008

[2] Blasting Safety Rules, GB6722-2014 